\title{
KLASIFIKASI DIAGNOSA PENYAKIT DEMAM BERDARAH DENGUE PADA ANAK MENGGUNAKAN METODE $K$-NEAREST NEIGHBOR STUDI KASUS RUMAH SAKIT PKU MUHAMMADIYAH UJUNG PANGKAH GRESIK
}

\author{
Rafika Amilia ${ }^{1}$, Eko Prasetyo ${ }^{2}$ \\ 1) Rumah Sakit PKU Muhammadiyah Ujung Pangkah \\ Jalan Raya Dandels No.21, Sekapuk, Ujungpangkah, Doudo, Kec. Panceng, Kabupaten Gresik, \\ Jawa Timur 61154 \\ 2)Teknik Informatika Universitas Muhammadiyah Gresik \\ Fakultas Teknik,Universitas Muhammadiyah Gresik \\ Jl. Sumatra 101 Gresik Kota Baru (GKB), Randuagung, 61121Telp \\ E-mail:rafikaamilia877@gmail.com ${ }^{1)}$
}

\begin{abstract}
ABSTRAK
Demam Berdarah Dengue (DBD) merupakan penyakit yang disebabkan oleh gigitan nyamuk Aedes yang terinfeksi salah satu dari empat tipe virus dengue dengan manifestasi klinis demam, nyeri otot dan atau nyeri sendi yang di sertai leukopenia, ruam, trombositpenia dan diathesis hemoragik. Ada 5 kriteria untuk menentukan seorang pasien dikategorikan positif atau negatif DB, yaitu variabel Usia pasien, Jenis kelamin pasien, peningkatan hemoglobin ( $\mathrm{Hb})$, peningkatan trombosit dan peningkatan hematrokit $(\mathrm{Ht})$ berdasarkan kriteria tersebut maka akan dilakukan klasifikasi data pasien positif dan negatif DBD dengan metode $K$-Nearest Neighbor berbasis web. metode K-Nearest Neighbor (KNN) memiliki kelebihan menghasilkan nilai error yang kecil. Algoritma KNN menggunakan klasifikasi ketetanggaan sebagai nilai prediksi dari sampel uji yang baru. Dekat atau jauhnya nilai tetangga biasanya dihitung berdasarkan jarak euclidean. Berdasarkan dari hasil penelitian dan pembahasan yang dilakukan, klasifikasi diagnose penyakit demam berdarah ini menggunakan algoritma KNN dengan variabel usia, jenis kelamin, hemoglobin, trombosit, hematrokit.
\end{abstract}

Kata kunci : Klasifikasi. Diagnosa. K-Nearest Neighhor. demam herdarah denoue

\section{PENDAHULUAN}

Rumah sakit PKU Muhammadiyah Ujung Pangkah adalah salah satu unit pusat kesehatan masyarakat yang berada di Kecamatan Ujung Pangkah Kabupaten Gresik dengan menyelenggarakan upaya kesehatan yang bersifat menyeluruh, terpadu, merata dan dapat diterima oleh masyarakat. Dengan perkembangan zaman yang semakin maju, maka banyak pula penyakit yang dapat menyerang manusia terutama penyakit-penyakit yang berbahaya
Salah satu penyakit berbahaya yang sering dijumpai adalah penyakit demam berdarah dengue (DBD). Dengan demikian maka perlu dibuatkan suatu sistem yang dapat mendiagnosa penyakit deman berdarah dengue (DBD) sehingga dapat memudahkan dokter dalam memberikan informasi atau arahan. 
INDEXIA: Informatic and Computational Intelegent Journal

Rafika Amilia, Eko Prasetyo

Klasifikasi Diagnosa Penyakit Demam Berdarah Dengue Pada Anak Menggunakan Metode K-Nearest Neighbor Studi

Kasus Rumah Sakit Pku Muhammadiyah Ujung Pangkah Gresik

Permasalahan yang dihadapi selama ini adalah banyaknya orang yang tidak mengetahui gejala dari penyakit demam berdarah dengue (DBD) sehingga Dokter harus cepat tanggap mengenali gejala penyakit demam berdarah dengue (DBD). Sebagian dari pasien yang mengalami demam berdarah akan berakhir dengan sakit yang serius. Pada penelitian sebelumnya yang pernah dibuat oleh (Hasibuan A.R, 2017 ) untuk tugas akhir dengan judul "Klasifikasi Diagnosa Penyakit Demam Berdarah Dengue (DBD) Menggunakan Support Vector Machine (SVM)". Teknik klasifikasi diagnose menggunakan metode Support Vector Machine (SVM) salah satu algoritma pembelajaran mesin yang di perkenalkan oleh vapnik yaitu bagaimana memisahkan dua kelas dengan suatu fungsi yang di peroleh dari data training yang tersedia. Konsep klasifikasi SVM dapat di jelaskan secara sederhana sebagai usaha mencari hyperplane terbaik yang berfungsi sebagai pemisah dua buah kelas data pada input space.

Pembuatan sistem klasifikasi diagnosa yang akan di lakukan pada penelitian ini menggunakan metode K-Nearest neighbor metode ini nantinya akan menghasilkan sebuah perhitungan yang diharapkan dapat mengklasifikasi diagnosa penyakit demam berdarah.MetodeK-Nearest Neighbor tepat digunakan untuk salah satu kasus klasifikasi dimana nilai $\mathrm{K}$ yang digunakan disini menyatakan jumlah tetangga terdekat yang dilibatkan dalam penentuan prediksi label kelas data uji. Kelas dengan jumlah suara tetangga terbanyaklah yang diberikan sebagai label hasil diagnosa pada data uji tersebut. Dari beberapa penelitian yang dilakukan dengan metode K-Nearest Neighbor (KNN) dapat dijadikan literature pada skripsi ini yang menggunakan metode klasifikasi diagnosa dengan $K$-Nearest Neighbor.
Pemilihan metode tersebut dikarenakan merupakan salah satu metode klasifikasi dimana data hasil dari sempel uji yang baru di klasifikasikan berdasarakan mayoritas dari kategori KNN. Algoritma KNN menggunakan klasifikasi ketetanggaan sebagai nilai prediksi dari sampel uji yang baru. Dekat atau jauhnya nilai tetangga biasanya dihitung berdasarkan jarak euclidean. Berdasarkan latar belakang tersebut, maka akan dilakukan penelitian masalah yang akan ditulis dalam bentuk tugas akhir dengan judul "Klasifikasi Diagnosa Penyakit Demam Berdarah Dengue (DBD) Pada Anak Menggunakan Metode K-NN (Studi Kasus : RS. PKU Muhammadiyah Ujung Pangkah Gresik)".

\section{LANDASAN TEORI \\ 2.1 Definisi Sistem}

Definisi sistem berkembang sesuai konteks dimana pengertian sistem itu digunakan. Berikut akan diberikan definisi sistem secara umum:

1. Kumpulan dari bagian-bagian yang bekerja sama untuk mencapai tujuan yang sama (Jogiyanto, H.M. 2005).

2. Sistem adalah kumpulan dari elemen-elemen yang berinteraksi untuk mencapai suatu tujuan tertentu (Jogiyanto, H.M. 2005).

3. Suatu sistem adalah jaringan kerja dari prosedur-prosedur yang saling berhubungan, berkumpul bersama-sama untuk melakukan suatu kegiatan atau untuk menyelesaikan suatu sasaran yang tertentu (Jogiyanto, H.M. 2005). 
INDEXIA: Informatic and Computational Intelegent Journal

Rafika Amilia, Eko Prasetyo

Klasifikasi Diagnosa Penyakit Demam Berdarah Dengue Pada Anak Menggunakan Metode K-Nearest Neighbor Studi

Kasus Rumah Sakit Pku Muhammadiyah Ujung Pangkah Gresik

4. Sistem merupakan kumpulan elemenelemen yang saling terkait dan bekerja sama untuk memproses masukan (input) yang ditujukan kepada sistem tersebut dan mengolah masukan tersebut sampai menghasilkan keluaran (output) yang diinginkan (Kadir A, Triwahyuni TCH. 2003).

Suatu sistem memiliki karakteristik atau sifat-sifat tertentu, yaitu:

1. Komponen sistem (components)

2. Batas sistem (boundary)

3. Lingkungan luar sistem (environments)

4. Penghubung sistem (interface)

5. Masukan sistem (input)

6. Keluaran sistem (output)

7. Pengolah sistem

8. Sasaran sistem (objective)

\subsection{Klasifikasi}

Menurut (Prasetyo, E, 2012), Klasifikasi dapat didefinisikan secara detail sebagai pekerjaan yang melakukan pelatihan/pembelajaran terhadap fungsi target $f$ yang memetakan setiap vektor (set fitur) $x$ ke satu dari sejumlah label kelas $y$ yang tersedia. Model dalam klasifikasi mempunyai arti yang sama dengan kotak hitam, di mana ada suatu model yang menerima masukan, kemudian mampu melakukan pemikiran terhadap masukan tersebut, dan memberikan jawaban sebagai keluaran dari hasil pemikirannya. Kerangka kerja (framework) klasifikasi ditunjukkan pada Gambar 2.1. Pada gambar tersebut, disediakan sejumlah data latih $(x, y)$ untuk digunakan sebagai data pembangunan model, kemudian menggunakan model tersebut untuk memprediksi kelas dari data uji $(\mathrm{x}, ?)$ sehingga data uji $(\mathrm{x}$, ?) diketahui kelas $y$ yang sesungguhnya.

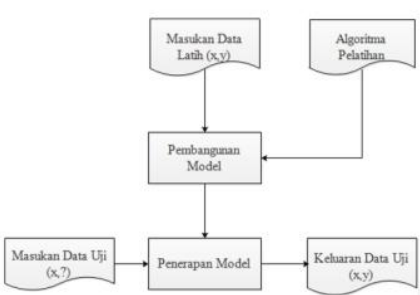

Gambar 2.1 Proses kerja klasifikasi

Model yang sudah dibangun pada saat pelatihan kemudian dapat digunakan untuk memprediksi label kelas data baru yang belum diketahui label kelasnya. Dalam pembangunan model selama proses pelatihan tersebut diperlukan adanya suatu algoritma untuk membangunnya yang disebut sebagai algoritma pelatihan (learning algorithm). Kerangka kerja seperti yang ditunjukkan pada Gambar 2.1 meliputi dua langkah proses yaitu induksi dan deduksi. Induksi merupakan suatu langkah untuk membangun model klasifikasi dari data latih yang diberikan, disebut juga proses pelatihan. Sedangkan deduksi merupakan suatu langkah untuk menerapkan model tersebut pada data uji sehingga data uji dapat diketahui kelas yang sesungguhnya atau disebut juga proses prediksi.

\subsection{Normalisasi Data}

Normalisasi data linier adalah proses penskalaan nilai atribut data sehingga bisa jatuh pada range tertentu. Tujuan dari normalisasi data adalah untuk mempersempit atau mengecilkan nilai range pada data tersebut. Normalisasi yang digunakan pada penelitian ini adalah min-max normalization yang merupakan proses transformasi nilai dari data yang dikumpulkan pada range value antara 0.0 dan 1.0, dimana nilai terkecil ( $\mathrm{min}$ ) adalah 0.0 dan nilai tertinggi ( $\max$ ) adalah 1.0 (Chandrasekhar, Thangavel dan Elayaraja, 2011). 
INDEXIA: Informatic and Computational Intelegent Journal

Rafika Amilia, Eko Prasetyo

Klasifikasi Diagnosa Penyakit Demam Berdarah Dengue Pada Anak Menggunakan Metode K-Nearest Neighbor Studi Kasus Rumah Sakit Pku Muhammadiyah Ujung Pangkah Gresik

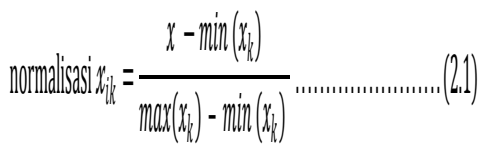

Keterangan :

$x_{i k} \quad=$ nilai hasil normalisasi

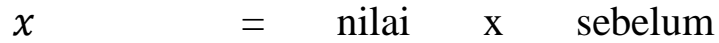

normalisasi

$\min \left(x_{k}\right)=$ nilai minimun dari fitur

$\max \left(x_{k}\right)=$ nilai maksimum dari fitur

\subsection{Metode K-Nearest Neighbor (KNN)}

K-Nearest Neighbors (KNN) adalah sebuah metode klasifikasi terhadap sekumpulan data berdasarkan pembelajaran data yang sudah terklasifikasikan sebelumnya. KNN termasuk dalam golongan supervised learning, dimana hasil query instance yang baru diklasifikasikan berdasarkan mayoritas kedekatan jarak dari kategori yang ada dalam KNN. Nantinya kelas yang baru dari suatu data akan dipilih berdasarkan grup kelas yang paling dekat jarak vektornya.

Tujuan dari algoritma ini adalah mengklasifikasikan obyek baru berdasarkan atribut dan training sample. Classifier tidak menggunakan model apapun untuk dicocokkan dan hanya berdasarkan pada memori. Diberikan titik query, akan ditemukan sejumlah k obyek atau (titik training) yang paling dekat dengan titik query. Klasifikasi menggunakan voting Algoritma $K$-Nearest Neighbors menggunakan klasifikasi ketetanggaan sebagai nilai prediksi dari query instance yang baru.

Metode K-Nearest Neighbors sangatlah sederhana, bekerja berdasarkan jarak terpendek dari query instance ke training sample untuk menentukan KNN- nya. Training sample diproyeksikan ke ruang berdimensi banyak, dimana masing- masing dimensi merepresentasikan fitur dari data. Ruang ini dibagi menjadi bagian-bagian berdasarkan klasifikasi training sample. Sebuah titik pada ruang ini ditandai jika kelas c merupakan klasifikasi yang paling banyak ditemui pada $\mathrm{k}$ buah tetangga terdekat dari titik tersebut. Dekat atau jauhnya tetangga biasanya dihitung berdasarkan Euclidean Distance.

Jarak Euclidean paling sering digunakan dalam menghitung jarak karena sangat cocok untuk menggunakan jarak terdekat (lurus) antara dua data. Jarak euclidean berfungsi menguji ukuran yang bisa digunakan sebagai interpretasi kedekatan jarak antara dua obyek yang direpresentasikan sebagai berikut:

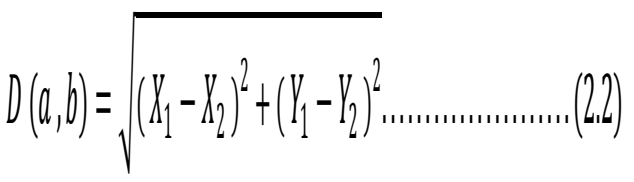

Keterangan :

$\mathrm{D}(\mathrm{a}, \mathrm{b})=$ Jarak Euclidean Data a dan Data $\mathrm{b}$

$\mathrm{X}=$ Koordinat titik $\mathrm{X}$

$\mathrm{Y} \quad=$ Koordinat titik $\mathrm{Y}$ 
INDEXIA: Informatic and Computational Intelegent Journal

Rafika Amilia, Eko Prasetyo

Klasifikasi Diagnosa Penyakit Demam Berdarah Dengue Pada Anak Menggunakan Metode K-Nearest Neighbor Studi

Kasus Rumah Sakit Pku Muhammadiyah Ujung Pangkah Gresik

\section{ANALISIS DAN PERANCANGAN SISTEM}

\subsection{Analisis Sistem}

Analisis sistem merupakan suatu proses melihat keseluruhan masalah dengan cara sistematis, menetapkan tujuan sistem, mengidentifikasi hambatan untuk mengidentifikasi pemecahan masalah tersebut. Analisis ini diperlukan sebagai dasar bagi tahapan perancangan sistem. Sistem yang akan dibuat merupakan sistem diagnosa penyakit demam berdarah dengue. Dengan adanya sistem ini maka diharapkan dapat mempermudah dokter dalam mendiagnosa beberapa pasien yang terkena atau tidak nya penyakit demam berdarah dengue.

Banyaknya masyarakat yang tidak menyadari dengan gejala penyakit demam berdarah mengakibatkan dinas kesehatan mengalami kesulitan dalam mengetahui banyaknya masyarakat yang terkena DBD. Pengendalian penyakit DBD dapat dilakukan dengan melakukan pendekatan faktor resiko dari penyakit demam berdarah.

\begin{tabular}{lrrr}
\multicolumn{2}{c}{ Sistem } & klasifikasi & diagnosa \\
penyakit & DBD pernah & dilakukan \\
penelitian & sebelumnya & dengan
\end{tabular}
menggunakan metode klasifikasi support vector machine (SVM) yaitu dengan memisahkan dua kelas dengan suatu fungsi yang diperoleh dari data training yang tersedia. Konsep klasifikasi dengan SVM dapat dijelaskan secara sederhana sebagai usaha mencari hyperplane terbaik yang berfungsi sebagai pemisah dua buah kelas data pada input space. Karena SVM terbukti memilih kinerja yang lebih unggul, karena telah mampu serratus persen mengklasifikasi data berdasarkan kelas yang tepat kemampuan generalisasi SVM sangat baik yaitu 95,4\%. terdapat dua proses pengenalan pada metode support vector machine (SVM) yaitu proses pembelajaran dan proses pengujian. Sehingga untuk memudahkan dalam mengklasifikasi diagnosa penyakit DBD akan digunakan dengan metode $K$ Nearest Neighbor diamana pada metode tersebut termasuk kedalam golongan supervised learning, dimana hasil query instance yang baru diklasifikasikan berdasarkan mayoritas kedekatan jarak dari kategori yang ada dalam $K$-Nearest Neighbor nantinya kelas yang baru dari suatu data akan dipilih berdasarkan grup kelas yang paling dekat jarak vektornya.

Data yang digunakan sebagai atribut yaitu data yang berhubungan dengan penyakit demam berdarah dengue seperti usia, jenis kelamin, hemoglobin, trombosit, hematrokit. Oleh karena itu pada sistem klasifikasi diagnosa ini akan dibagi kedalam kategori kelas positif dan kelas negatif. Dengan demikian dokter dapat memberikan informasi atau arahan kepada pasien agar terhindar atau meminimalkan dari serangan penyakit demam berdarah.

\subsection{Hasil Analisis}

Hasil analisis yang didapat adalah sistem klasifikasi ini dapat membantu dokter untuk mendukung keputusan yang tepat mengenai bagaimana penanganan yang sesuai berdasarkan tingkat pasien untuk mempercepat proses penyembuhan dan mencegah kemungkinan terburuk bagi pasien dengan mengklasifikasikan tingkat pasien yang positif dan negatif terkena demam berdarah dengue. Pembuatan aplikasi klasifikasi metode $K$-Nearest Neighbor dibutuhkan data pembelajaran, data tersebut didapatkan dari data rekam medis di Rumah Sakit PKU Muhammadiyah Ujung Pangkah Gresik. 
INDEXIA: Informatic and Computational Intelegent Journal

Rafika Amilia, Eko Prasetyo

Klasifikasi Diagnosa Penyakit Demam Berdarah Dengue Pada Anak Menggunakan Metode K-Nearest Neighbor Studi

Kasus Rumah Sakit Pku Muhammadiyah Ujung Pangkah Gresik

Data tersebut akan diolah menggunakan metode K-Nearest Neighbor yaitu berupa keluaran positif atau negatif. Sistem yang akan dibangun termasuk kedalam sistem pengelompokan (clustering). Sistem yang dibuat harus mampu mendiagnosa pasien penderita demam berdarah berdasarkan data dari rekam medis menggunakan teknik klasifikasi data mining dengan metode K-Nearest Neighbor. Sistem yang akan dibangun ditujukan untuk digunakan dokter dalam menentukan diagnosa pasien penyakit demam berdarah dengue. Sistem ini akan menghasilkan nilai keluaran berupa kategori positif atau negatif. Terdapat beberapa atribut yang dibutuhkan untuk mengklasifikasikan pasien terkena atau tidaknya diantaranya usia, jenis kelamin, hemoglobin, trombosit, hematrokit. Pada Gambar 3.1 akan menjelaskan bagaimana proses alur sistem pada aplikasi sistem klasifikasi diagnosa penyakit demam berdarah dengue.

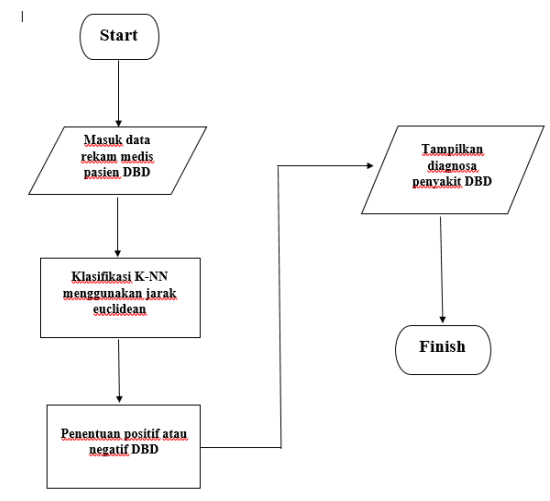

Gambar 3.1 Flowchart sistem klasifikasi diagnosa penyakit demam berdarah
Penjelasan untuk Gambar 3.1 :

1. Pertama memasukkan data rekam medis pasien yang positif dan negatif terkena demam berdarah dengue.

2. Sistem akan mulai melakukan proses perhitungan klasifikasi dengan menggunakan metode $K$-Nearest Neighbor (KNN) dimana menggunakan perhitungan kedekatan jarak Euclidean, nanti nya kelas yang baru dari suatu data akan di pilih berdasarkan grup kelas yang paling dekat dengan jarak vektornya.

3. Setelah dilakukan proses klasifikasi dan telah menentukan hasil akhir, selanjutnya menentukan diagnosa pasien demam berdarah dengue berdasarkan hasil keluaran kelas baru dari proes perhitungan klasifikasi.

4. Selanjutnya sistem akan menampilkan keluaran hasil diagnosa pasien demam berdarah dengue yang masuk kedalam kategori positif (1) atau negatif (2).

Sedangkan untuk gambar diagram alir dari metode $K$-Nearest Neighbor dapat dilihat pada Gambar 3.2

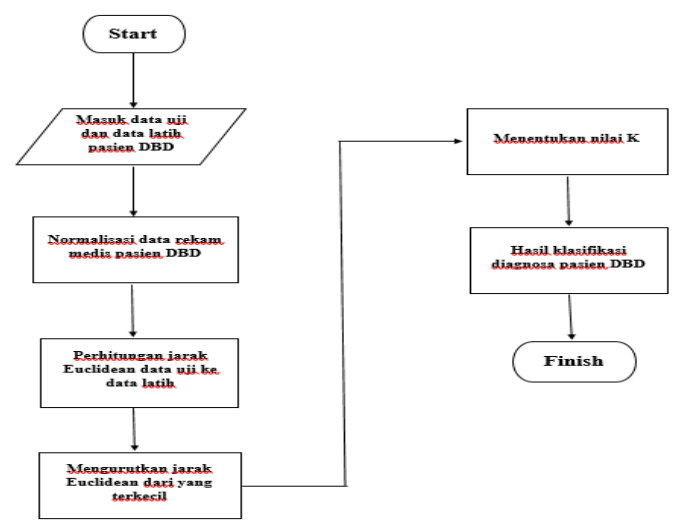

Gambar 3.2 Flowchart sistem metode $K$ Nearest Neighbor 
INDEXIA: Informatic and Computational Intelegent Journal

Rafika Amilia, Eko Prasetyo

Klasifikasi Diagnosa Penyakit Demam Berdarah Dengue Pada Anak Menggunakan Metode K-Nearest Neighbor Studi Kasus Rumah Sakit Pku Muhammadiyah Ujung Pangkah Gresik 
INDEXIA: Informatic and Computational Intelegent Journal

Rafika Amilia, Eko Prasetyo

Klasifikasi Diagnosa Penyakit Demam Berdarah Dengue Pada Anak Menggunakan Metode K-Nearest Neighbor Studi Kasus Rumah Sakit Pku Muhammadiyah Ujung Pangkah Gresik

\subsection{Diagram Konteks}

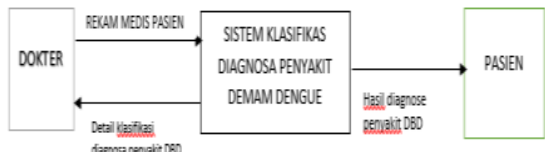

Gambar 3.3 Diagram Konteks

Penjelasan dari Gambar 3.3 terlihat bahwa stackholder atau entity yang terlibat dalam sistem ini adalah dokter dan pasien. Dokter memasukkan data rekam medis pasien penyakit demam berdarah dengue sebagai data uji dan data latih yang terdiri dari umur, jenis kelamin, hemoglobin, trombosit, hematrokit Kemudian akan diproses didalam sistem klasifikasi penyakit demam berdarah dengue dengan menggunakan metode $K$ Nearest Neighbor. Selanjutnya dokter akan menerima hasil detail klasifikasi diagnosa pasien dari sistem dan laporan diagnosa penyakit demam berdarah dengue akan diberikan untuk pasien.

\subsection{Diagram Berjenjang}

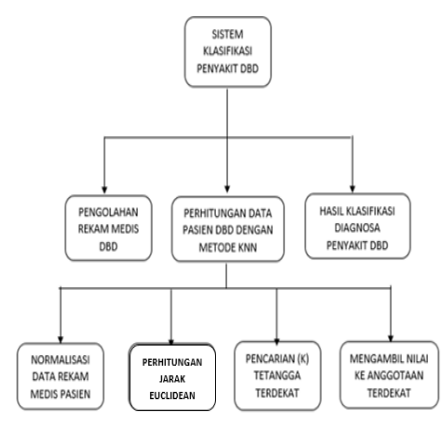

Gambar 3.4 Diagram Berjenjang
Diagram berjenjang disajikan pada

Gambar 3.4 berikut penjelasannya:

Top Level : sistem klasifikasi penyakit demam berdarah dengue di Rumah sakit PKU Muhammadiyah Ujung pangkah Gresik

Level 0 :

1. Pengelolahan data rekam medis

2. Perhitungan diagnose pasien penyakit demam berdarah dengue dengan metode K-Nearest Neighbor.

3. Laporan klasifikasi diagnosa pasien demam berdarah dengue.

Level 1 :

2.1 Normalisasi data rekam medis pasien

2.2 Perhitungan Jarak Euclidean

2.3 Pencarian K tetangga terdekat

2.4 Mengambil nilai keanggotaan terdekat.

\section{IMPLEMENTASI DAN} PENGUJIAN SISTEM

\subsection{Pengujian Satu Data}

Data rekam medis yang didapat akan dilakukan satu pengujian data uji, contoh kasus dari permasalahan sebagai berikut:

1. Seorang pasien gagal ginjal kronis memiliki data rekam medis umur $=$ 53 , bun $=47.5$, kreatinin $=3.93, \mathrm{hb}=$ 11.1, lfg $=25.56, \mathrm{bb}=62$ dan $\mathrm{jk}=$ laki-laki. Masukkan data tersebut pada menu pasien, kemudian lakukan uji klasifikasi data rekam medis dengan nilai $\mathrm{K}$ yang sudah ditentukan seperti pada Gambar 6. 
INDEXIA: Informatic and Computational Intelegent Journal

Rafika Amilia, Eko Prasetyo

Klasifikasi Diagnosa Penyakit Demam Berdarah Dengue Pada Anak Menggunakan Metode K-Nearest Neighbor Studi Kasus Rumah Sakit Pku Muhammadiyah Ujung Pangkah Gresik

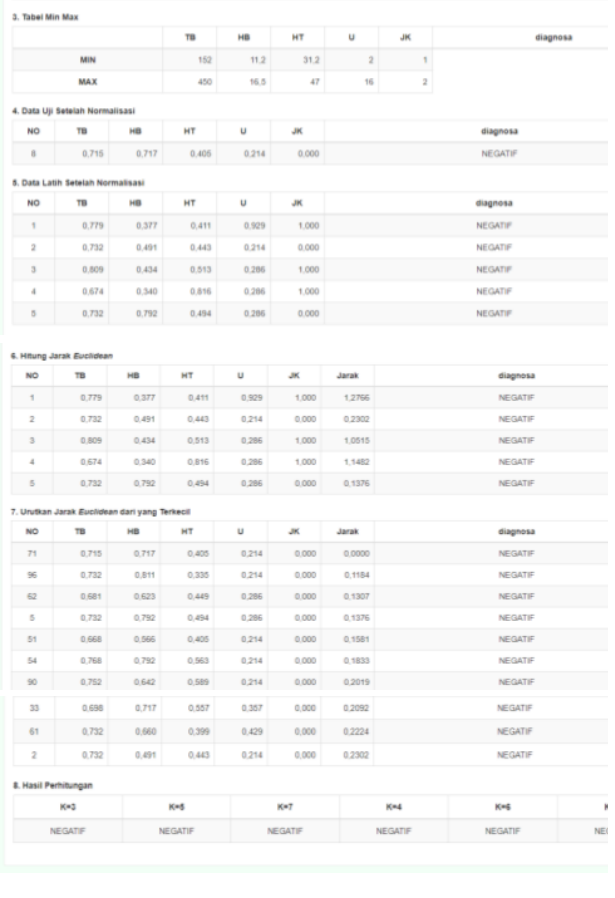

Gambar 6 Hasil klasifikasi satu data

Hasil diagnosa dari semua $\mathrm{K}$ disajikan pada Gambar 6 keluaran klasifikasi semua $\mathrm{K}$ hasil perhitungan yang sudah di tentukan dari data uji pasien tersebut termasuk dalam diagnosa penyakit demam berdarah dengue . Hasil klasifikasi ini tergantung dari data rekam medis pasien yang dimasukkan.

\subsection{Keberhasilan Sistem Klasifikasi}

$\begin{array}{ccc}\text { Terdapat } & 1 \text { kali } & \text { skenario } \\ \text { percobaan } & \text { dimana } & \text { skenario }\end{array}$
percobaan memiliki jumlah proporsi data latih Tabel 2 menunjukkan hasil perbandingan pengujian dari skenario pertama dan skenario kedua menggunakan proses normalisasi data.

Tabel 1 Hasil skenario pengujian dengan proses normalisasi data

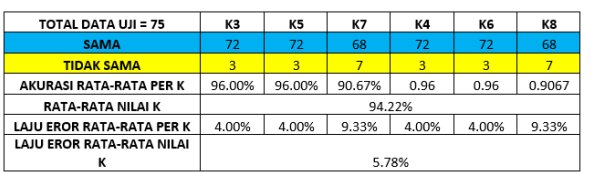

\section{KESIMPULAN dan SARAN 5.1 Kesimpulan}

Hasil yang didapatkan dari penelitian ini dapat disimpulkan sebagai berikut:

1. Sistem ini menggunakan metode K-Nearest Neighbor (KNN) dengan parameter umur, jenis kelamin, hemoglobin, trombosit, hemotrokit yang akan digunakan untuk mendeteksi dini diagnosa penyakit dbd.

2. Berdasarkan hasil perhitungan confusion matrix untuk pengujian 150 data latih dan 75 data uji sistem ini memiliki nilai $\mathrm{K}$ terbaik yaitu $94,22 \%$ pada $\mathrm{K}=3 \mathrm{~K}=5 \mathrm{~K}=7 \mathrm{~K}=4, \mathrm{~K}=6$, dan $K=8$, nilai $K$ terbaik diatas dapat digunakan untuk acuan klasifikasi selanjutnya.

\subsection{Saran}

Saran yang akan diberikan untuk mengembangkan penelitian ini adalah sebagai berikut:

1. Perlu adanya pengembangan pada desain tampilan antarmuka agar lebih menarik bagi para pengguna.

2. Perlu ditambahkan fasilitas help pada sistem dengan tujuan agar dapat membantu user dalam menggunakan sistem tersebut.

3. Perlu dibuatkan sistem backup agar data-data yang telah ada akan tersimpan dengan baik. 
INDEXIA: Informatic and Computational Intelegent Journal

Rafika Amilia, Eko Prasetyo

Klasifikasi Diagnosa Penyakit Demam Berdarah Dengue Pada Anak Menggunakan Metode K-Nearest Neighbor Studi Kasus Rumah Sakit Pku Muhammadiyah Ujung Pangkah Gresik

\section{DAFTAR PUSTAKA}

Kadir A, Triwahyuni TCH. 2003. Pengenalan Teknologi Informasi. Yogyakarta: Andi

Kristina, Isminah, Wulandari L. 2004. Kajian Masalah Kesehatan Demam Berdarah Dengue.

http:www.litbang.depkes.go.id

Lestari, M. 2014. Penerapan Algoritma Klasifikasi Nearest Neighbor ( $K$ NN) Untuk Mendeteksi Penyakit Jantung. Universitas Indraprasta, Jakarta Selatan.

Prasetyo, E. 2012. Data Mining - Konsep dan Aplikasi Menggunakan Matlab. Yogyakarta: Andi Offset.

Prasetyo, E. 2014. Data Mining Mengelolah Data Menjadi Informasi Menggunakan Matlab. Yogyakarta: Andi Offset.
Suhendro et al, 2006. Demam Berdarah

Dengue. Jakarta: Pusat Penerbitan Departemen Ilmu Penyakit Dalam. Fakultas Kedokteran Universitas Indonesia.

Tan, P. et al. 2006. Introduction to Data Mining. Boston: Pearson Education.

Tiaratuni dan Sudaryanto. 2014. Pengertian Data Mining dan Sifat Data Mining. Diakses 15 Februari 2017 